Instructions for authors, subscriptions and further details:

http://remie.hipatiapress.com

\title{
The Difficulties of DESIGN TRAIN-ing
}

Nazan Kirci ${ }^{1}$

1) Gazi University. Turkey

Date of publication: June $15^{\text {th }}, 2017$

Edition period: June 2017-October 2017

To cite this article: Kirci, N. (2017). The Difficulties of DESIGN TRAIN-ing. Multidisciplinary Journal of Educational Research, 7(2), 184-215. doi: 10.17583/remie.2017.2237

To link this article: http://dx.doi.org/10.17583/remie.2017.2237

\section{PLEASE SCROLL DOWN FOR ARTICLE}

The terms and conditions of use are related to the Open Journal System and to Creative Commons Attribution License (CC-BY). 


\title{
The Difficulties of DESIGN TRAIN-ing
}

\author{
Nazan Kirci \\ Gazi University
}

\section{Abstract}

First year architecture students have difficulties to adapt to the new language of architectural discourse. This depends on the student's individual capabilities and adequacies as well as the department's methodology of teaching and the tutorstudent relationship. In respect of $1^{\text {st }}$ year design education, it has been thought that the opinions of the learners are an important source for feedbacks for the revision and improvement of education planning strategies of the teachers. This study, which has been based on ten departments of architecture in Turkey, has been formed to reveal these difficulties from the students' point of view by means of a survey. This survey consists of interpretative questions that are related to the pre-requisites of vocational education, difficulties in learning, the evaluation of students' comprehension of basic design principles and various difficulties of educational process. The subjects that the students struggle with have been identified at the end of the survey and then the suggestions of the students offering a solution for this issue have been passed on.

Keywords: vocation, first year architectural education, basic design, technical drawing, student proposals 


\title{
Dificultades de la Formación en Diseño
}

\author{
Nazan Kirci \\ Gazi University
}

\section{Resumen}

Los estudiantes de primer año de arquitectura tienen dificultades para adaptarse al nuevo lenguaje del discurso arquitectónico. Esto depende de las capacidades y adecuaciones individuales del estudiante, así como de la metodología de enseñanza del departamento y de la relación tutor-alumno. En cuanto a la valoración de la formación del primer año en diseño, se han considerado las opiniones del alumnado como una fuente importante de retroalimentación para la revisión y mejora de las estrategias de planificación educativa del profesorado. Este estudio, que se ha basado en diez departamentos de arquitectura en Turquía, revela, las dificultades observadas desde el punto de vista de los estudiantes a través de una encuesta. Esta encuesta consiste en preguntas interpretativas que se relacionan con los requisitos previos de la formación profesional, las dificultades en el aprendizaje, la evaluación de la comprensión de los estudiantes de los principios básicos del diseño y las diversas dificultades del proceso educativo. Al final de la encuesta se identifican los temas con los que los estudiantes se enfrentan y se transmiten también las sugerencias que los estudiantes ofrecen como solución a este problema.

Palabras clave: vocación, primer año de educación arquitectónica, diseño básico, dibujo técnico, propuestas de estudiantes 


\section{Kirci - The difficulties of DESIGN TRAIN-ing}

$\mathrm{T}$ he main task of the 1st Year Education is to establish the concept of Design Thinking in the minds of the students. While the process they come across challenging and provocative practices. This study had been undertaken to determine what these challenges are from the point of view of the students.

The term 'Design Thinking' has been part of the collective consciousness of design researchers since Rowe (1987) used it as the title of his book. Multiple models of design thinking have emerged since then, based on widely different ways of viewing design situations and using theories and models from design methodology, psychology, education, etc. Together, these streams of research create a rich and varied understanding of a very complex human reality (Dorst, 2011).

Since architecture is a special field within the domain of design, many specific methods have been developed for the establishment and improvement of the idea of architectural design in students' minds. Such methods have to do with how design is defined first and foremost. For example; design is defined by Quayle (1985) as "the process of developing appropriate physical solution in response to specific needs of people and the environment." On the other hand, while talking about the design process, Glanville (1999) emphasizes the necessity or importance of creativity and identifies the act of designing as more than just problem solving. Alternatively, Blumrich (1970) defines designing as finding a solution to a previously unsolved problem or doing it in a way that has never been tried.

Creativity as a natural component of design process has often been characterised by the 'creative leap' that occurs between problem and solution space. Since the nature of creativity is so complex, there is no single definition that fully encompasses this concept and identifies a solution as creative. So, there can be no guarantee that a creative 'event' will occur during a design process (Demirkan \& Afacan, 2012).

Architectural product has got many qualities telling it apart from other fields of design. Most valuable aspects of educational expectations of the students in design education come to light as subjects which help them to gain the attributes, skills and knowledge in the field by the help of which they can be creative, innovative, can help them solve problems, help them 
design artefacts that respond to human needs. Their expectancies in design process and in the content of courses located in curriculum are also parallel to these subjects. They want more knowledge in methods for developing creativity, courses for creativity (Cartier, 2011).

\section{What is the Specific of the First Year Architectural Education}

Cultural background and having a "designer" way of thinking are very important (Cross, 1982). The inadequate preparation resulting from a students' high school education and their insufficient cultural and technical background are seen to have a negative effect. Empirical studies indicate that the learning styles of designers are systematically different from those of other professional groups (Cross, 1991), and this has obvious relevance to designers' ways of viewing the world and responding to different environments.

Most students of architecture enter higher education with little experience of this form of learning, and therefore a large part of architectural education is concerned with the development of new abilities, values and conceptions, so that eventually they are able to think and do as architects. For new students in architecture, a move to a system where the answers are uncertain, and the route to that endpoint ambiguous (Lawson, 1997) and not following any set methodology, may prove a frustrating and difficult challenge (Roberts, 2006).

\section{Problem Parameters}

The problem parameters, which are the actors of the difficulties that the students face in their first year education, are various. However, they can be summarized as such:

- The characteristics of the students (their learning styles, their personal characteristics)

- The methodology of education

- Tutor - student relationship

During the scrutiny of these aspects, it is going to be apparent that they are in fact interconnected. 


\section{The Characteristics of the Student}

Design education essentially deals with teaching how to design, moreover, rather ideally, with guiding students to discover their own ways of designing (Ulusoy, 1999).

Whereas academic success is closely related to how the student learns and the student's personal characteristics. However, it is difficult to find the answer that would comply with all different qualifications.

In the literature, learning styles are considered as a kind of general strategy, for example characterised as surface-level or deep-level processing (Marton \& Saljoé, 1976), a holistic vs a serialistic style (Pask, 1976, 1988), deep processing, elaborative processing, fact retention and methodical study (Schmeck, 1983). Learning styles are also described as types of learning like, for example, concrete experience, reflective observation, abstract conceptualization and active experimentation, resulting in four learning styles: divergers, accommodators, convergers and assimilators (Kolb, 1976, 1984), as orientations like achieving, meaning, reproducing and nonacademic (Entwistle, 1988), or as approaches to learning like surface, deep and achieving (Busatoa, Prinsb, Elshouta, \& Hamakera, 2000). Many of the most important personality dispositions may be considered as collectively comprising the 'Big Five' traits of the Five Factor Model of personality (Farsidesa \& Woodfield, 2003). These factors are usually named extraversion, agreeableness (sociability), conscientiousness, neuroticism and openness to experience (intellect or culture) (Busatoa, Prinsb, Elshouta \& Hamakera, 2000).

As it has been briefly summarized above, the manners of learning and personal characteristics of people differ a great deal. Accordingly, it is evident that one has to show flexibility and comprehensiveness in the selection of the teaching methods to be applied to the students whose personal characteristics are different from each other.

\section{The Methodology of Education}

Much of architectural education is concerned with developing students in order for them to become well rounded, competent and imaginative 
designers of buildings and the spaces between them. Since architectural education is studio-based learning process, design work cannot put forward a single correct solution. During this process, the student is invited to make propositions which are often exploratory and speculative. Their responses are likely to be unique and individualistic, and owe more to interpretation and intuition than to a logical or formulaic process (Schön, 1985).

Faculty are divided internally often according to the bipolar distinction of architecture as a technocratic profession or an art-between nuts-and-bolts faculty, who insist that schools should transmit primarily practical/ technical skills, and those who argue that the school's primary function is to provide training in different aesthetic ideologies (Crysler, 1995).

Studio-based approaches have been widely adopted as a general educational foundation for design education. From a learning perspective, the studio as a medium for design education has been characterized by certain endemic problems (Oxman, 1999). Thus, in the introductory design education, the objectives, the content and the methods should be set much more carefully (Farivarsadri, 2001)

\section{Tutor - Student Relationship}

Students are so indoctrinated to their pre-college system that it is difficult for them to become open to learning, and willing to experiment. The reciprocal learning-teaching relationship is a phenomenon in the design studio.

The relationship between the student-tutor started to gain importance at the Bauhaus. The Bauhaus Teaching Theory brought some innovations to architectural education, unlike the Ecole des Beaux-Art Architectural School Education style, as instead of the imitation of classical architecture to actively create a new project by students, the master was more passive, being a guide to the student in the design process (Danaci, 2015).

The teachers also serve as social models for their students. However, fostering creativity via social modelling has two limitations. The first limitation is that creative tutors are by definition rare to come by. Moreover, by tradition, teaching aims at convergence more than divergence. Tutors are to ensure that students learn what is prescribed by 


\section{Kirci - The difficulties of DESIGN TRAIN-ing}

the curriculum so as to fulfill the cultural transmission or recreation function of education.

The second limitation is that there may be a lack of emotionalties between tutors and students. Ideally, a positive social-motional relation prevails in the classroom, but the reality is that not all tutors are admired by their students (Soh, 2017).

Let alone the students, even the teacher may not be sufficiently prepared for this interesting process. As Glasser (2000) has put it plainly; most tutors, found themselves in beginning teaching situations, without mentors or clear direction, obliged to transmit knowledge and skills as best they could. As is the case for many entering teachers, without having had the opportunity to test and evaluate these basic assumptions in the field.

It is possible to classify knowledge as explicit and tacit. Explicit knowledge is sometimes referred to as know-what. Tacit knowledge was originally defined by Polanyi in 1966. He claimed that we had envisaged tacit knowing in the first place as a way to know more than we can tell (Polanyi, 2009, p. 18). This knowledge unexpectedly can reflect our work. Through Schön's (1985), "reflection-in-action" the "designerly" (Cross, 1982) ways of thinking and acting can be "known" by the students. Schön (1985) has pointed out that there are several levels of learning in the process of reciprocal reflection-in-action: "The student learns both about designing and about learning to design...Further, the student learns about design in the same process by which she learns about designing". In other words, the subject (design) and the ways to grasp the subject (designing/learning) are both gained together by the student. Although tutor-student are involved in the same process (studio guiding), the reciprocal reflection-in-action focuses on design as their mutual goal. So, the interaction between student and master in the design studio may enhance the student's learning and the master's teaching on design (Chen, Heylighen \& Neuckermans, 2006).

Empirical studies often emphasize the cognitive style of communication between the tutor and the student (Oxman, 2004). A tutor, has many ways of "telling" (Schön, 1989, p.102). Domain knowledge becomes explicit as the significant component to be taught and transferred in education. Through modeling, conceptual knowledge is acquired as well as cognitive 
processes in design. The student functions as a design researcher while learning about design, in addition to how to design (Oxman, 2004).

\section{Case Study}

In order to define the problem by means of determining the difficulties that students face within departments of architecture, a survey has been carried out among architecture department students of 10 universities in Turkey: Çukurova University, Erciyes University, Mersin University, Y1ldı Technical University, Selçuk University, Mimar Sinan University, Gazi University, İzmir Institute of Technology, Kocaeli University, and İstanbul Technical University. The urban planning department of İzmir Institute of Technology and the urban planning and interior design department of İstanbul Technical University have also been included within the survey, since those students take the same courses in their first year of education. In this survey, in order for students to objectively evaluate both themselves and the method carried out in their universities, they were not asked to give their identification information.

\section{Data Categories}

The survey consists of four parts. Within the framework of the survey, the below mentioned subjects are considered nationally within Turkey:

1- The factors that affect the choice of the specific vocation,

2- The level of the students' interest for the vocation,

3- The subjects with which students have difficulties,

4- The suggestions of the students to their own problems.

The calculated Cronbach Alpha co-efficient for the trustworthiness of the survey is $\alpha=0.834$. According to this, the questions are highly trustworthy.

Table 1.

Reliability Statistics

\begin{tabular}{lll}
\hline $\begin{array}{l}\text { Cronbach's } \\
\text { Alpha }\end{array}$ & $\begin{array}{l}\text { Cronbach's Alpha Based } \\
\text { on Standardized Items }\end{array}$ & N of Items \\
\hline 0.834 & 0.750 & 48 \\
\hline
\end{tabular}




\section{Data Evaluations}

1. The factors that affect the choice of vocation. This part of the survey consists of questions related to the entrance to the vocation. The willingness of the students to the vocation, the reason for their choice of architecture, former knowledge about architectural education and design, and the compatibility of this knowledge with what that they have learned during their education process are all topics that were asked.
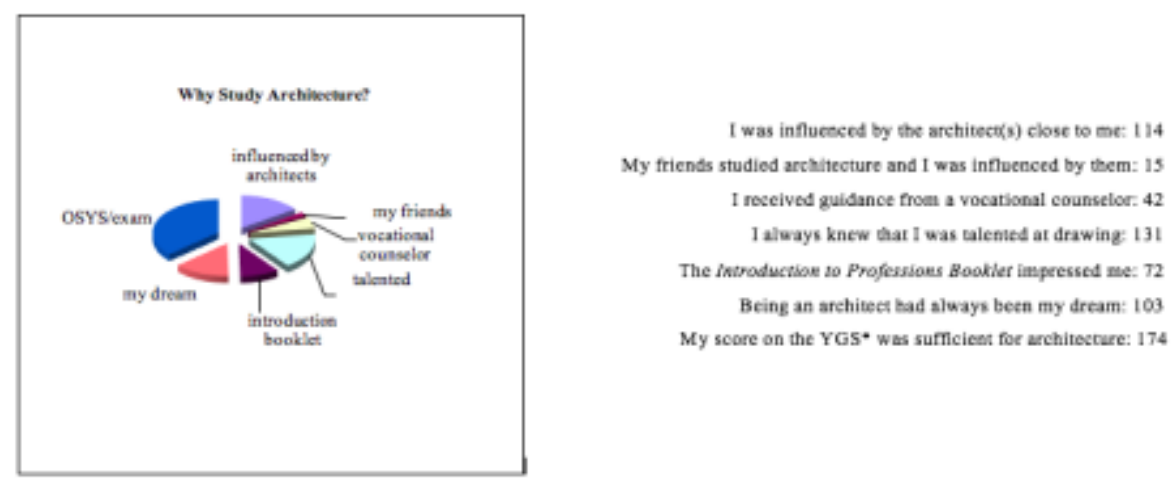

* Student Selection and Placement Examination

Figure 1. The factors that affect the choice of students.

In Turkey, students are accepted to both state and private universities according to the results of a multiple-choice national exam in mathematics, science and reading comprehension. Just like students of engineering departments, entrance to architecture departments is determined from their scores. As a result, students' desire for different departments, in other words their "eagerness," is determined according to their success in the national exam. In such circumstances, eagerness to architectural education will appear to be in below ranks and students will participate to architecture education without any "eagerness". Consequentially, students were requested to answer whether or not they eagerly wanted to study architecture. Among the 450 surveyed participants, 147 said that they 
eagerly chose architecture, and 38 stated that they did not want to come to an architecture department eagerly. In order to clarify the reasons that made students choose to study architecture, students were requested to mark one or more choices below. The choices and the number of students that marked each choice are given below according to rank.

The determinant role of the Turkish University Entrance Examination (YGS) on students' choice of architecture departments can be clearly seen in the survey results, since 174 students answered that the amount of points scored on the exam determined their choice. Conversely, the guidance of vocational counselors and introductory booklets can also be seen as not as effective as other influences (See Figure 1).

2. Level of interest in the vocation/architecture. As a result of the survey, it can be clearly seen that although 321 participants stated they had previous knowledge about architecture and/or architectural education, 129 stated that they had no idea about what architecture or architectural education was (See Figure 2). Although the amount of students that had previous knowledge about architecture is not low, when compared with countries that put emphasis on the role of interest and adequacy of students in their choice of vocation, the amount can be seen as remarkably inadequate.

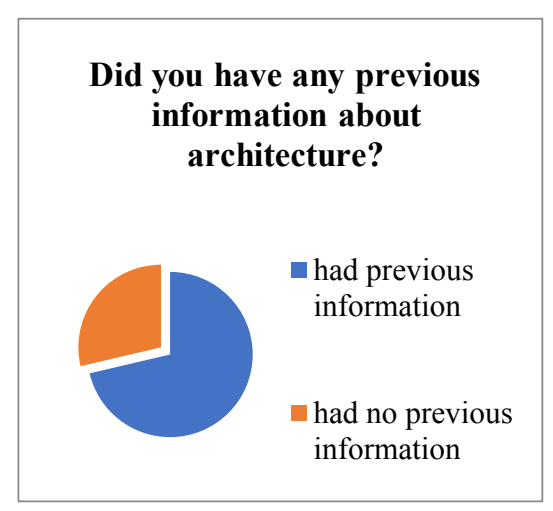

Figure 2. Previous knowledge about architecture. 


\section{Compatibility of previous information}

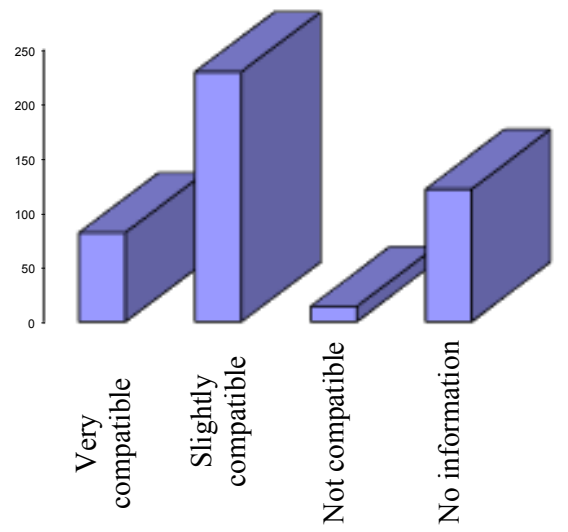

Figure 3. Compatibility of previous information with initial experiences in architecture

Students were also requested to reply whether or not the information they acquired before their entrance to architectural departments was compatible with the experience acquired after admission to their department. From those who had previous knowledge about architecture, 82 stated that knowledge was very compatible with what they acquired during their architectural education; 230 stated that their previous information about architecture was slightly compatible with their experiences at architecture departments, and 14 stated that there was no compatibility (See Figure 3). As a result of the survey it can be seen that the majority of the students had neither adequate nor accurate previous knowledge about architecture.

In universities that accept architecture students via a skills test (rather than the national university entrance exam), the interest of the students about the vocation is evaluated with reference to their knowledge of famous figures in architectural history and their well-known buildings. In order to evaluate such an interest, the students were asked to answer the question 
"Did any building in your surrounding or in films and periodicals take your attention before you entered to your architecture department?" While 9 of the students answered "never," 270 replied "sometimes" and 170 said that buildings "attracted their attention very much" (See Figure 4).

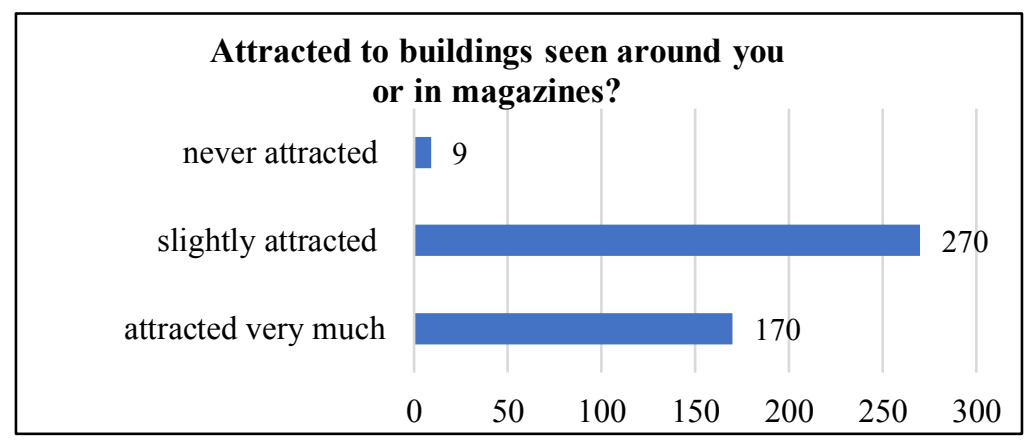

Figure 4. Attraction to the surrounding buildings.

In order to weigh up this interest, the students were then asked the question "Did you know any famous architect or building before you entered your department of architecture?" While 242 replied "yes," 206 said "no" to this question (See Figure 5). In answer to this question, Architect Sinan was the most known national architect, and Frank Lloyd Wright, Mies van der Rohe, Zaha Hadid, Frank Gehry and Santiago Calatrava were all equally observed to be the most known international architects.

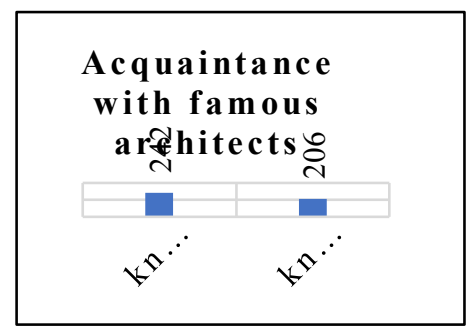

Figure 5. Acquaintance with famous architects. 
When compared with the students' familiarity of representational techniques as the communicatory tool of architecture, the amount of "yes" answers to this question about famous architects was observed to be higher, most likely the result of the non-supportive role of the Turkish high school education. The question "Did you know technical drawing before you entered your department of architecture?" was answered affirmatively by only 20 of students. On the other hand, 74 answered the question as "I knew a little" and 355 said that they did not have any knowledge about the representational techniques of architectural practice. As a result of this question, it can be said that the technical language of architectural practice is a little known subject among architecture students prior to studying architecture (See Figure 6).

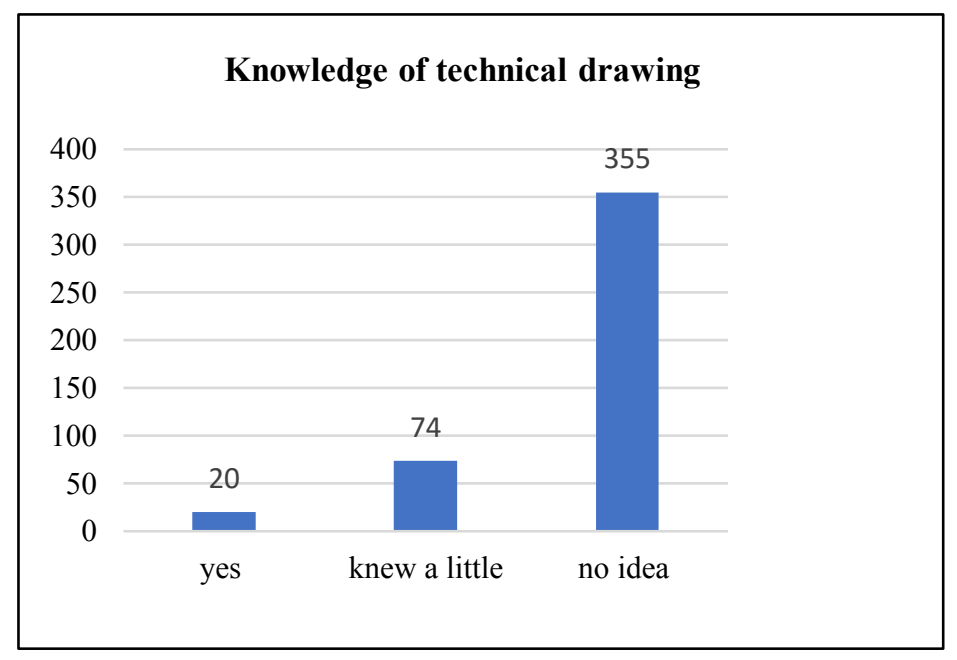

Figure 6. Knowledge of Technical Drawing

\section{The most difficult subjects to comprehend during the educational} process. For the first year of architectural education, which is an introduction to architectural design, architectural representation techniques 
- technical drawing - are taught with the support of the basic design studio education. For this period, which consists of three stages, an elaborate study has been made to reveal the problems that students face during this early learning process.

a. Technical drawing and social issues. By means of a Likert scale students were asked to express their ideas on the subjects below.

Questions (A-5), (A-6), (B-1) and (B-3) are seen to be the most difficult subjects to understand (See Table 2 in Annex A). The most easily understood questions seem to be (A-2) and (B-2). In Turkey, students are accepted to universities according to their scores on national evaluation exams called YGS. With this in mind, to see if there is a direct relationship between students who claim the results of the national university exam as an essential factor for their choice of department and those students who do not, a comparative study has been made on the range of difficulties in understanding the subjects provided in Table 9. For this reason, by means of a One-Sample Kolmogorov-Smirnov Test, an inquiry has been made to check these factors. In the final tables, since $\mathrm{p}=0.00<\alpha=0.05$, all the data fits well to the normal distribution. Therefore, a non-parametric test was made and the validity of the two hypotheses was analyzed by means of a Mann-Whitney test.

$H_{0}$ : Both examples have the same median distribution. (There is no difference between examples.)

$H_{1}$ : The examples do not have the same median distribution. (There is a difference between the two examples.) These two hypotheses are structured as same for the other questionnaires.

If the "p" value in Asymp. Sig. (2-tailed) is compared with $\alpha=0.05$, a comparison of the answers to questions (A-1-8) and (B-1-3) (See Table 3 in Annex A).

Question A-1 (perceiving the depth of objects and reflecting that in drawing) $\mathrm{p}=0.027<\alpha=0.05 H_{0}$ is ignored. That is to say, there appears to be a meaningful statistical difference between the effectiveness of the national exam or not. Similarly, question A-8 (drawing the section of an 


\section{Kirci - The difficulties of DESIGN TRAIN-ing}

object from its perspective and dimensions) $\mathrm{p}=0.026<\alpha=0.05 H_{0}$ is also ignored. Among the other analyzed subjects, there is no meaningful statistical difference between effectiveness of the national exam or not.

The data was also tested to see if there was a difference between students who thought that they had drawing ability before entering university and those who thought they understood the subjects of technical drawing. When the "p" value which is in Asymp. Sig. (2-tailed) is compared with $\alpha=0.05$ the following results are achieved.

For question A-2 (changing scales and working with measurements), since as $\mathrm{p}=0.956>\alpha=0.05, H_{0}$ is not ignored. That is, for changing scales, it is seen that there is no statistical difference between believing in the ability to draw or not. Similarly, for question A-6 (drawing the section of an object from its plan and elevation), since $\mathrm{p}=0.056>\alpha=0.05 H_{0}$ is not ignored. In this respect, it is seen that there is no statistical difference between students who believe in their drawing ability and those students who do not. For the questions in the table other than these two, since the $\mathrm{p}$ value $<\alpha=0.05$ it is seen that the students who believe in their drawing abilities do not have any difficulty, have easily understood the mentioned subjects and do not have difficulties in coping with them (See Table 3 in Annex A).

Similar to these questions, by means of a Mann-Whitney Test, those students who previously thought of architecture as vocation were compared with those students who did not, in terms of their state of understanding the subjects on B. Abstract and Social Issues.

According to the comparison between " $p$ " value and $\alpha=0.05$ in Asymp. Sig. (2-tailed), the results are as follows: for question B-1 (studying with abstract concepts), because $\mathrm{p}=0.010<\alpha=0.05, H_{0}$ is ignored. That is, it is seen that on the subject of studying with abstract concepts there is a meaningful difference in statistical results between students who imagined architecture as their vocation since his/her childhood and those did not. For questions B-2 (coping with human requirements and easily managing them) and B-3 (struggling with more than one subject in the design process), since the "p" value is $>\alpha=0.05, H_{0}$ is not ignored. In brief, there is no 
meaningful statistical difference between students who have imagined architecture as their future vocation and those who did not (See Table 4 in Annex A).

For question A-2 (to change scales), since $\mathrm{p}=0.122>\alpha=0.05, H_{0}$ is not ignored. That is, for the subjects on "changing scales" or "studying with measurements," there is no meaningful statistical difference between students who had prior knowledge about technical drawing and those who did not. This is also same for question A-3 (making a model of a design) since $\mathrm{p}=0.055>\alpha=0.05, H_{0}$ is not ignored (See Table 5 in Annex A).

b. Basic design comprehension. In this part of the study, students were asked to evaluate their "understanding" of basic design principles using (1 2 very difficult), (3-4 a little bit difficult), (5-6 not so difficult), (7-8 easy), (9-10 very easy) (See Table 2 in Annex A). Students who did not mark any answers are not included in the evaluation. In this way, the total amount of the students participating in the study decreased from 400 to 352 .

As a result of this part of the study, symmetry/asymmetry and repetitionrhythm are the most easily understood subjects, while the concept of hierarchy is seen to be the least comprehended concept. The comparison of understanding of basic design principles by those students who believe in their drawing ability and those who do not is again made with a MannWhitney Test (See Table 6 in Annex A).

As a result of this study, it can be seen that there appeared no meaningful statistical difference between students who believe in their drawing ability and those who did not according to their evaluation of basic design concepts of Measure/Ratio/Proportion, Harmony, Contrast, Dominance, Texture, Hierarchy, Repetition-Rhythm, Symmetry/Asymmetry Figure-Ground relationship, and Solid-Void relationship. For the subject of Unity $(\mathrm{p}=0.026<\alpha=0.05)$ and the subject of Light-Shadow relationship $(\mathrm{p}=0.002<\alpha=0.05), H_{0}$ is ignored. For these two subjects, a meaningful statistical difference between students who believe in their drawing ability and those who did not can be seen: those who believed in their drawing ability asserted that these two subjects were easy (See Table 7 in Annex A). 
The comprehension of basic design principles was also analyzed in terms of the students' former knowledge about architecture.

Since $\mathrm{p}=0.017<\alpha=0.05,{ }^{H_{0}}$ is ignored. That is, in terms the topic of hierarchy, a meaningful statistical difference between students who had previous knowledge about architecture and those who did not can be seen. Those students with previous knowledge declared that the concept of hierarchy was easy for them. For the other basic design principles, there appeared to be no meaningful statistical difference (See Table 8 in Annex A).

c. Difficulties in the education process. This part of the questionnaire consists of seven questions concerning the difficulties of the architectural educational process.

- (C-1) Not knowing the way my design is going to be evaluated hardened my perception regarding the method I should choose.

- (C-2) The fact that there is no single "correct" answer makes it difficult for me to understand whether my work will succeed or not.

- (C-3) The fact that there are not many resource books I can use as reference makes it difficult for me to proceed with my work.

- (C-4) The fact that the resource books I use are not directly related to my area of search makes it difficult for me to proceed with my work

- (C-5) The studio tutors should not make use of examples too frequently

- (C-6) I find it hard to use group instructions while working on my own.

- (C-7) I am quite shy while interacting with the studio tutor personally and therefore cannot ask everything I should. 


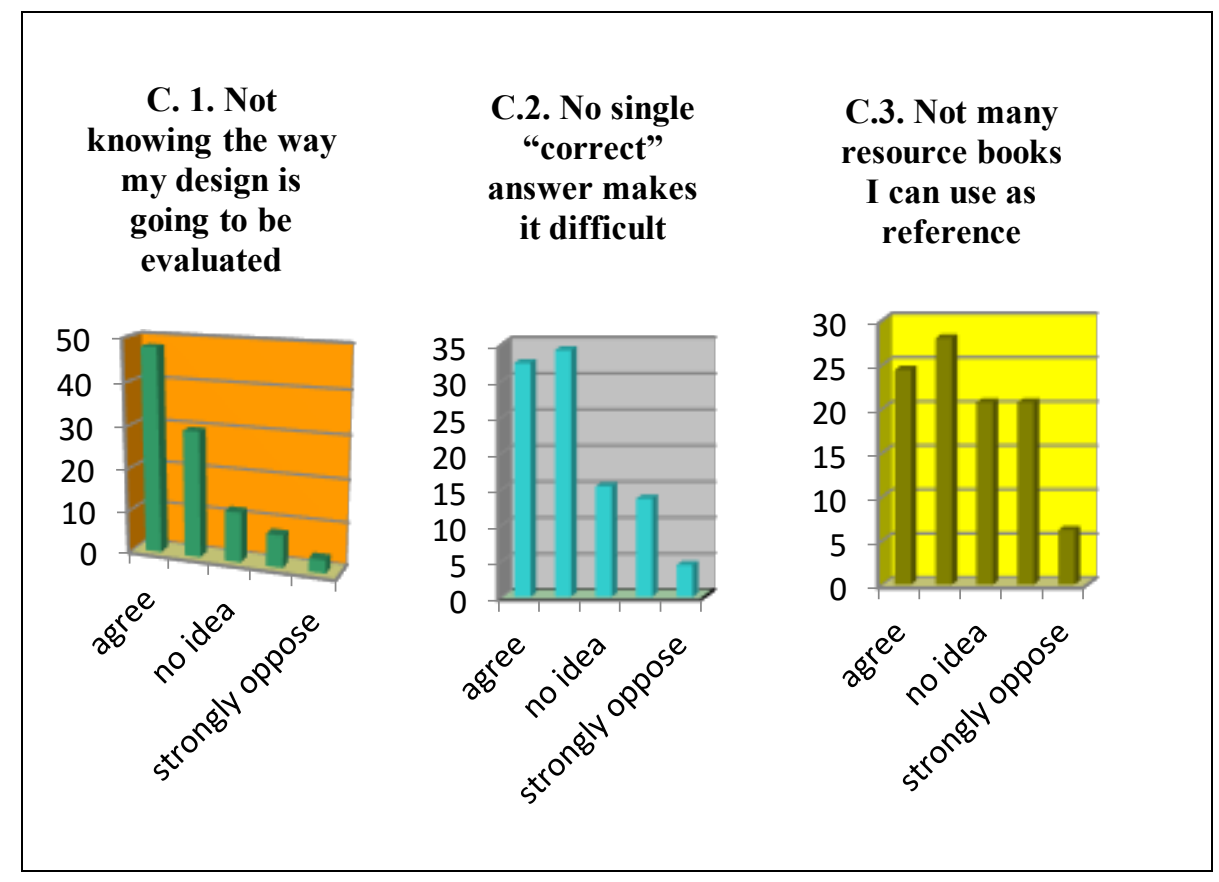

Figure 7. Evaluation of C.1, C.2, and C.3.

It is seen that most of the students accepted comments (C-2) and (C-3). For the interpretational question $(\mathrm{C}-3)$, the first year students specifically expressed their difficulties on the small amount of convenient resource books available to them (See Figure 7).

With regards to question (C-4), the students expressed that the existing books' methodology (not providing the answer in the shortest way as they are used to) as a difficulty. 
C.4. The resource books I shall use are not directly related to my area of search

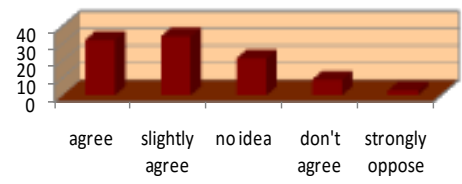

C.5. Instructors should not teach the lessons by making use of examples too frequently

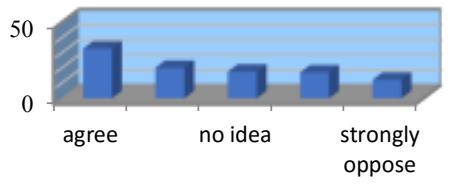

Figure 8. C.4 and C.5 evaluation.

For question (C-5), which contains a negative connotation, the amount of "I agree" answers are seen to be more than the "I don't agree" and "strongly oppose" answers in comparison with previous questions, which reveals that perhaps the students are not carefully reading and understanding all the questions (See Figure 8).

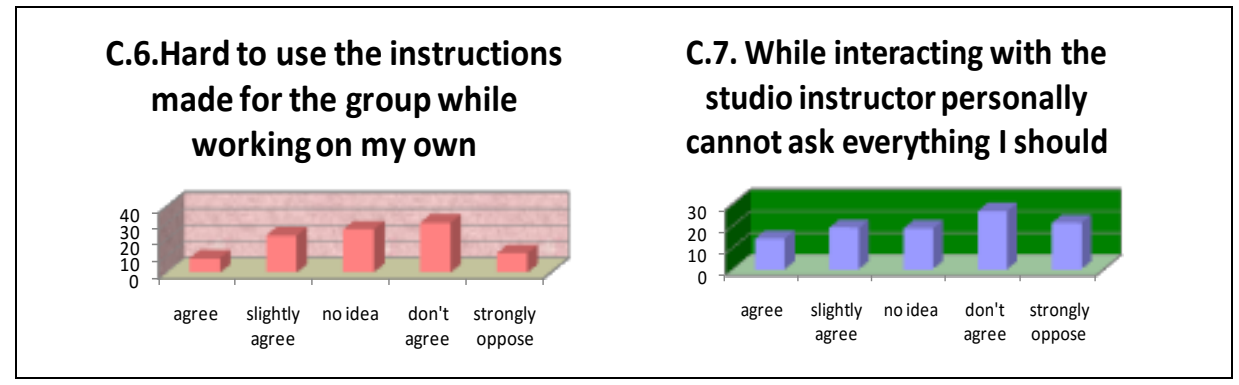

Figure 9. C.6 and C.7 evaluation.

Because the statistical density of non-committals weighs towards the "I don't agree" answer for question (C-6), it is inferred that the students can make use of group instructions. As a result of question $(\mathrm{C}-7)$, it is seen that 
although there are non-committal students, most students do not face such kind of a difficulty (See Figure 9).

3. Students' own solutions to their difficulties. To the question "do you think that with another methodology the subject could become more easily understandable?" 79 students answered "yes" and 205 said "maybe". Among all the students, although 41 of them answered that the current methodology was "useless" and 7 said "worthless," 118 students answered that they were non-committal about the subject. If the non-committed answered are ignored, it can be asserted that the majority of students (284) are in hope of a new method other than an existent educational methodology.

Although on the one hand 358 students did not propose a new methodology, on the other hand 92 did propose a different method or working methodology. The majority of these 92 proposals emphasized the necessity of the introduction of digital technologies to the modern way of education. They claimed that with the aid of digital technologies, the teaching of most subjects would be better. They also stated that the process of architectural production would be easier if 3D modeling tools are taught better or more effectively. They also mentioned the importance of animations and video presentations. Additionally, the students also emphasized the essentiality of model making or teaching with models to better understand three-dimensional design. The importance of learning architecture through national and international travel was also indicated by the students. They recalled the importance of the tutors' behavior specifically for the first year education on their development and future plans. Moreover, they focused on the necessity of human psychology and physiology lessons, teaching with exemplary models and the importance of model laboratories in architecture departments.

\section{Results}

In Turkey, it can be asserted that the major criterion for entering architectural education is the national university exam: the YGS (Student Selection and Placement Centre). 


\section{Kirci - The difficulties of DESIGN TRAIN-ing}

The students' tendency to choose the subject and their attraction from architects that they know are some other factors that follow their exam results. Other than the exam results, the students' tendency to select the subject might be because of their proximity to and admiration for an architect that they know. On the contrary, it has been observed that career consultation services and vocational introductory booklets are not so effective in students' choices to study architecture. Only $18 \%$ of the students expressed that what they knew about architecture matched their experiences while studying in the first year. This reveals the fact that the current presentation of the vocation is not adequate for students to gain prior knowledge about the study of architecture.

Despite the majority of students claiming an interest in architecture culture, it has been seen that the amount of the students who had acquaintance with an architect or his/her work was much less. Additionally, it has been observed that their knowledge and interest of the subject was not so deep. For example, the amount of students who did not know technical drawing was $79 \%$.

According to the arithmetic average of the survey, it has been seen that the subjects of structural systems, perspectival drawing of objects whose dimensions are known, and sectional drawing of objects whose dimensions and perspective is known are difficult to understand. The students stated that they have difficulties in abstract thinking and coping with complex problems. Among the concepts related with basic design, the students declared that "hierarchy" was the least successful subject.

The survey questions on the difficulties of learning and comprehending basic design principles were tested in order to observe the effects of some chosen criteria. For instance, in the comparison between students who stated that the student selection and placement exam was a determinative role in their choice to study architecture and those for whom it was not, it has been seen that difference occurs in "conceiving the depth of objects" and "drawing the section of an object when the dimensions and perspective are known." In the comparison between those who believe that they have drawing ability and those who believe they do not, the evaluation of "to change scale and to work with measurements" and "to draw the section of an object from its plan and elevation" were observed to be different. 
Students who knew technical drawing seem to have more easily overcome the subjects of architectural representation techniques; however, this knowledge did not provide them any advantage for the topics "to form the design into a model..."

The question "was it difficult for you to design with abstract concepts?" in the survey was answered as "yes, it was hard" by a majority of the students. However, the students who claim it was their dream to study architecture, had easily got to grips with the situation. So it was concluded that a prior interest in and a motivation for architecture has positive effects on learning the subject.

The comparison of basic design principles between students who had previous drawing ability and those who stated that they had previous knowledge about architecture resulted in different evaluations on the subjects of unity, light-shadow and hierarchy, but there was no determinative statistical difference observed among the other basic design principles.

In their answers to the interpretation questions, the students stated that they had difficulties because they did not know the method and form of evaluation, that there was no one "correct" accepted answer and that there were no reference sources which directly formulized the taught subjects. $63 \%$ of the students thought that some other pedagogical methods different than the ones carried out would be more satisfactory. However, only $20 \%$ of these students were able to come up with alternative proposals. They asserted that computer modeling would ease the learning process and video shows and animations should also be integrated into the teaching program. They also stated that teaching the subjects from models would be effective in order to understand the third dimension and they also emphasized the importance of international trips. Moreover, the students also proposed model laboratories, the study of ergonomics and environmental psychology, and a supportive rather than antagonistic pedagogic approach of the tutors.

\section{Discussion and Conclusion}

The students' interest in the vocation of architecture, being rightly informed about the vocation and having the necessary basic knowledge, are some 


\section{Kirci - The difficulties of DESIGN TRAIN-ing}

important factors that will increase the success of the students during and after education. According to the survey, it can be asserted that for students who are relatively close to architecture culture (the ones who have previous knowledge of the subject or the ones who have a relative who is an architect), the beginning of architectural education is easier. It has been understood that such knowledge provides them with the designerly way of knowing as described by Cross (1982).

The challenges related with the first year education could be eased by way of updating the content and method of teaching. Since the subject of abstract conceptualism is expressed as a general challenge, overcoming this could relieve the weight of the system. And for this to be done, the students are offered computer aided-, model- and animation-based education to better understand the study of three dimensions. It has been observed that any change to the content and method would provide both the students and the tutors a better and comfortable process of education. Students require supportive activities to be creative in multi-input problems and to get used to multi-dimensional, flexible thinking. This could be organized as extraor in-curricular activities to introduce them into architecture culture. To provide these facilities before university education would prevent some of the problems before they occur. The revision of pre-university education to support the academician architects tries to decrease difficulties with respect to their knowledge and interest areas. Specifying what the problem is from the student's point of view will be an important supportive source to enhance the productivity of these studies.

\section{Acknowledgments}

The author would like to thank Çukurova, Erciyes, Mersin, Yıldız Technical, Selçuk, Mimar Sinan, Izmir Technology, Kocaeli- and Istanbul Technical Universities for their contribution to the study. Additionally, the author would like to thank Sibel Açık Alemdaroğlu, Betül Koç, Ozlem Sağıroğlu and Meltem Şarman for their contribution in survey and evaluation of it. Lastly, the author would like to thank Christopher Wilson for his careful proofreading of the English text. 
REMIE - Multidisciplinary Journal of Educational Research, 7(2) 207

\section{References}

Blumrich J. F. (1970). Design. Science, 168 (3939), 1551-1554. doi: 10.1126/science.168.3939.1551

Busatoa, V. V., Prinsb, F. J., Elshouta, J. J., \& Hamakera, C. (2000). Intellectual ability, learning style, personality, achievement motivation and academic success of psychology students in higher education. Personality and Individual Differences, 29, 1057-1068. doi: 10.1016/S0191-8869(99)00253-6

Cartier, P. (2011). Most valuable aspects of educational expectations of the students in design education. Procedia-Social and Behavioral Sciences, 15, 2187-2191. doi: 10.1016/j.sbspro.2011.04.077

Chen J. D., Heylighen A., \& Neuckermans H. (2006). Learning Design Teaching. In Al-Qawasmi, J., \& de Velasco, G. P. V. (Eds.), Changing Trends in Architectural Design Education (pp. 577-588). Rabat, Morocco: CSAAR.

Cross N. (1982). Designerly ways of knowing. Design Studies, 3(4), 221227. doi: 10.1016/0142-694X(82)90040-0

Cross N. (1991). Research in design thinking. Design Studies, 12, 3-10. doi: 10.1162/074793601750357196

Crysler, C. G. (1995). Critical Pedagogy and Architectural Education. Journal of Architectural Education, 48(4), 208-217. doi: 10.1080/10464883.1995.10734644

Danaci, H. M. ( 2015). Creativity and knowledge in architectural education. Procedia - Social and Behavioral Sciences, 174, 1309-1312. doi: 10.1016/j.sbspro.2015.01.752

Demirkan, H., \& Afacan, Y. (2012). Assessing creativity in design education: analysis of creativity factors in the first-year design studio. Design Studies, 33, 262-278. doi:

10.1016/j.destud.2011.11.005

Dorst, K. (2011). The core of 'design thinking' and its application. Design Studies, 32, 521-532. doi: 10.1016/j.destud.2011.07.006

Entwistle, N. J. (1988). Motivational factors in students' approaches to learning. In R. R. Schmeck, (Ed), Learning Strategies and Learning Styles (pp. 21-51). Edinburgh: Scottish Academic Press. 
Farivarsadri, G. (2001, setember). Critical view on pedagogical dimension of introductory design in architectural education. Paper presented at the meeting of Architectural Education Exchange (AEE), Cardiff University, England. Retrieved from http://cebe.cf.ac.uk/aee/pdfs/farivarsadrig1.pdf

Farsidesa, T. \& Woodfield, R. (2003). Individual differences and undergraduate academic success: the roles of personality, intelligence, and application. Personality and Individual Differences, 34, 12251243. Retrieved from

https://pdfs.semanticscholar.org/ee61/7cf9791bf54a9afb1f4e2ae5fc83 e706dffa.pdf

Glanville, R. (1999). Researching design and designing research. Design Issues, 15(2), 80-91. doi: 10.2307/1511844

Glasser, D. E. (2000). Reflections on architectural education. Journal of Architectural Education, 53(4), 250-252. doi: 10.1162/104648800564662

Kolb, D. A. (1976). The Learning Style Inventory: Technical Manual, Boston, Ma.: McBer.

Kolb, D. A. (1984). Experiential Learning, Englewood Cliffs, NJ.: Prentice Hall.

Lawson, B (1997). How designers think: the design process demystified. Oxford: Architectural Press.

Marton, F., \& Saljo, R. (1976). On qualitative differences in learning. I. Outcome and process. British Journal of Educational Psychology, 46, 4-11. doi: 10.1111/j.2044-8279.1976.tb02980.x

Oxman, R. (1999). Educating the designerly thinker. Design Studies, 20(2) 105-122. doi: 10.1016/S0142-694X(98)00029-5

Oxman, R. (2004). Think-maps: teaching design thinking in design education. Design Studies, 25(1), 63-91. doi: 10.1016/S0142694X(03)00033-4

Pask, G. (1976). Styles and Strategies of Learning. British Journal of Educational Psychology, 46, 128-48.

Pask, G. (1988). Learning strategies, teaching strategies and conceptual or learning style. In R. R. Schmeck (Ed.), Learning strategies and learning styles. New York: Plenum Press.

Polanyi, M. (2009). The tacit dimension. Chicago: University of Chicago Press. 
Roberts, A. (2006). Cognitive styles and student progression in architectural design education. Design Studies, 27(2), 167-181. doi:

10.1016/j.destud.2005.07.001

Rowe, P.G. (1987). Design Thinking. Cambridge, MA: MIT Press.

Schön, D (1985). The design studio: an exploration of its traditions and potentials. London: RIBA Publications.

Schön, D. (1989). Educating the reflective practitioner. San Francisco: Jossey-Bass publishers.

Schmeck, R. R. (1983). Learning Styles of college students. In R. F. Dillon \& R. R. Schmeck (Eds.), Individual differences in cognition (pp. 233279). New York: Academic Press.

Quayle M. (1985). Idea book for teaching design. Mesa, AZ: PDA Publisher Corporation.

Soh, K. (2017). Fostering student creativity through tutor behaviors.

Thinking Skills and Creativity, 23, 58-66. doi:

10.1016/j.tsc.2016.11.002

Ulusoy, Z. (1999). To design versus to understand design: the role of graphic representations and verbal expressions. Design Studies, 20(2), 123130. doi.org/10.1016/S0142-694X(98)00030-1

Nazan Kirci is Associate Professor at the Department of Architecture, Gazi University, Turkey.

Contact Address: Department of Architecture. Faculty of Architecture, 06570, Maltepe Ankara.

E-mail: nazkirci@gmail.com 
210 Kirci - The difficulties of DESIGN TRAIN-ing

\section{ANNEX A}

Table 2

The evaluation and the effect of factors

\begin{tabular}{|c|c|c|c|c|c|c|c|c|c|}
\hline $\begin{array}{l}\text { (A-Technical drawing issues...) } \\
\text { (B- Abstract and social issues } \\
\ldots \text {..) } \\
\text { were difficult for me. }\end{array}$ & 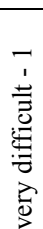 & 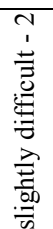 & 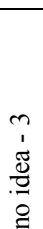 & 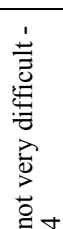 & 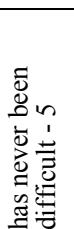 & 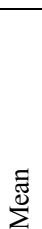 & 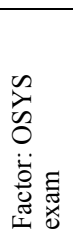 & 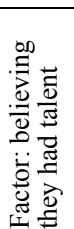 & 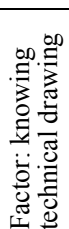 \\
\hline
\end{tabular}

(A-Technical drawing issues...)

(A-1) Perceiving the depth of objects and reflecting that in drawing

(A-2) Changing scales and working with measurements

(A-3) Making a model of a design

(A-4) Drawing plan/section and elevation of a threedimensional model of an object

(A-5) Perceiving the structural system of three dimensional objects and expressing this in technical drawing

(A-6) Drawing the section of an object from its plan and elevation

(A-7) Drawing the perspective of an object from its plan, elevation and section

(A-8) Drawing the section of an object from its perspective and dimensions

\section{(B- Abstract and social issues ...)}

(B-1) Making design on an abstract concept

(B-2) While designing a project, to know the needs of its users and to meet them accordingly

(B-3) When I was asked to design something, I realized that I should reflect on many different issues. Coping with this was...

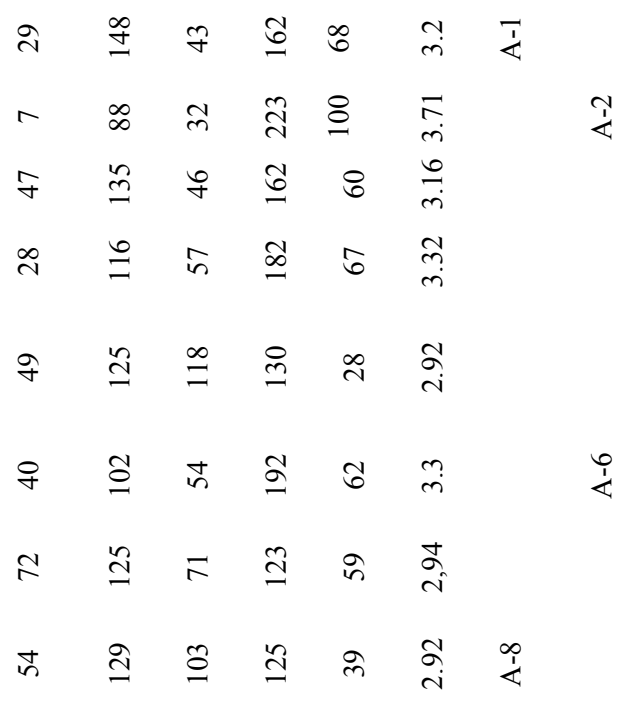

Factor: Dreaming architecture

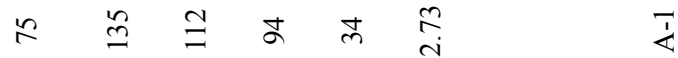

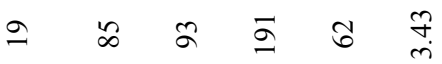

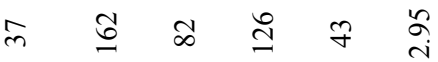


REMIE - Multidisciplinary Journal of Educational Research, 7(2) 211

Table 3

Ranks Grouping Variable: OSYS

Test Statistics(a)

\begin{tabular}{|c|c|c|c|c|c|c|c|}
\hline & $(\mathrm{A}-1)$ & $(\mathrm{A}-2)$ & \multicolumn{2}{|c|}{ (A-3) } & $(\mathrm{A}-4)$ & $(\mathrm{A}-5)$ & $(A-6)$ \\
\hline $\begin{array}{l}\text { Mann- } \\
\text { Whitney U }\end{array}$ & 21169.000 & 23297.000 & \multicolumn{2}{|c|}{21741.500} & 23067.000 & 22125.000 & 22280.000 \\
\hline $\begin{array}{l}\text { Wilcoxon } \\
\text { W }\end{array}$ & 36394.000 & 61523.000 & \multicolumn{2}{|c|}{36966.500} & 38292.000 & 37350.000 & 37505.000 \\
\hline Z & -2.214 & -0.574 & \multicolumn{2}{|c|}{-1.760} & -.737 & -1.453 & -1.355 \\
\hline $\begin{array}{l}\text { Asymp. } \\
\text { Sig. (2- } \\
\text { tailed) }\end{array}$ & 0.027 & 0.566 & \multicolumn{2}{|c|}{0.078} & 0.461 & 0.146 & 0.176 \\
\hline & $(\mathrm{A}-7)$ & \multicolumn{2}{|c|}{$(\mathrm{A}-8)$} & \multicolumn{2}{|c|}{ (B-1) } & (B-2) & (B-3) \\
\hline Wilcoxon W & 21559.500 & \multicolumn{2}{|c|}{21102.500} & \multicolumn{2}{|c|}{22938.500} & 22619.500 & 23913.000 \\
\hline $\mathrm{Z}$ & 36784.500 & \multicolumn{2}{|c|}{36327.500} & \multicolumn{2}{|c|}{38163.500} & 60845.500 & 39138.000 \\
\hline $\begin{array}{l}\text { Asymp. Sig. } \\
\text { (2-tailed) }\end{array}$ & -1.875 & \multicolumn{2}{|c|}{-2.233} & \multicolumn{2}{|c|}{-0.823} & -1.089 & -0.077 \\
\hline $\begin{array}{l}\text { Mann- } \\
\text { Whitney U }\end{array}$ & 0.061 & \multicolumn{2}{|c|}{0.026} & \multicolumn{2}{|c|}{0.411} & 0.276 & 0.939 \\
\hline
\end{tabular}

Table 4

Ranks Test Grouping Variable: talented at drawing

Statistics (a)

\begin{tabular}{lcccccccc}
\hline & $(\mathrm{A}-1)$ & $(\mathrm{A}-2)$ & $(\mathrm{A}-3)$ & $(\mathrm{A}-4)$ & $(\mathrm{A}-5)$ & $(\mathrm{A}-6)$ & $(\mathrm{A}-7)$ & $(\mathrm{A}-8)$ \\
\hline $\begin{array}{l}\text { Mann- } \\
\text { Whitney }\end{array}$ & 14523.00 & 20830.00 & 17585.00 & 17600.00 & 18254.50 & 18614.50 & 16745.00 & 16995.50 \\
$\mathrm{U}$ & & & & & & & & \\
$\begin{array}{l}\text { Wilcoxon } \\
\text { W }\end{array}$ & 65563.00 & 71870.00 & 68625.00 & 68640.00 & 69294.50 & 69654.50 & 67785.00 & 68035.50 \\
$Z$ & -5.320 & -0.056 & -2.751 & -2.754 & -2.179 & -1.912 & -3.401 & -3.208 \\
$\begin{array}{l}\text { Asymp. } \\
\begin{array}{l}\text { Sig. (2- } \\
\text { tailed) }\end{array}\end{array}$ & 0.000 & 0.956 & 0.006 & 0.006 & 0.029 & 0.056 & 0.001 & 0.001 \\
\hline
\end{tabular}


212 Kirci-The difficulties of DESIGN TRAIN-ing

Table 5

Ranks Grouping Variable: dream

Test Statistics (a)

\begin{tabular}{lccc}
\hline & $\begin{array}{c}\text { (B-1) abstract } \\
\text { concept }\end{array}$ & (B-2) user needs & $\begin{array}{c}\text { (B-3) complicated } \\
\text { issues }\end{array}$ \\
\hline Mann-Whitney U & 14959.000 & 17063.500 & 16826.500 \\
Wilcoxon W & 75337.000 & 22419.500 & 77204.500 \\
Z & -2.586 & -.732 & -.937 \\
$\begin{array}{l}\text { Asymp. Sig. } \\
\text { (2-tailed) }\end{array}$ & .010 & .464 & .349 \\
\hline
\end{tabular}

Table 6

Ranks Grouping Variable: single line 2

Test Statistics (a)

\begin{tabular}{lcccccccc}
\hline & $(\mathrm{A}-1)$ & $(\mathrm{A}-2)$ & $(\mathrm{A}-3)$ & $(\mathrm{A}-4)$ & $(\mathrm{A}-5)$ & $(\mathrm{A}-6)$ & $(\mathrm{A}-7)$ & $(\mathrm{A}-8)$ \\
\hline $\begin{array}{l}\text { Mann- } \\
\text { Whitney }\end{array}$ & 11767.00 & 15122.50 & 14667.50 & 11564.00 & 13876.50 & 12187.00 & 12129.00 & 12973.00 \\
$\mathrm{U}$ & & & & & & & & \\
$\begin{array}{l}\text { Wilcoxon } \\
\text { W }\end{array}$ & 75313.00 & 78668.50 & 78213.50 & 75110.00 & 77422.50 & 75733.00 & 75675.00 & 76519.00 \\
$Z$ & -4.633 & -1.548 & -1.917 & -4.828 & -2.633 & -4.259 & -4.216 & -3.456 \\
$\begin{array}{l}\text { Asymp. } \\
\begin{array}{l}\text { Sig. (2- } \\
\text { tailed) }\end{array}\end{array}$ & 0.000 & 0.122 & 0.055 & 0.000 & 0.008 & 0.000 & 0.000 & 0.001 \\
\hline
\end{tabular}


REMIE - Multidisciplinary Journal of Educational Research, 7(2) 213

Table 7.

Evaluation of the difficulty of basic design principles

\begin{tabular}{|c|c|c|c|c|c|c|c|}
\hline $\begin{array}{l}\text { basic design } \\
\text { principles }\end{array}$ & 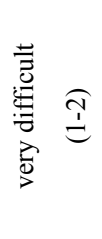 & 孚 & $\begin{array}{l}6 \\
1 \\
\qquad \\
c\end{array}$ & $\underset{\substack{\infty \\
c}}{c}$ & 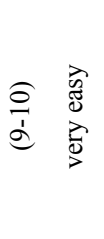 & 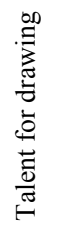 & 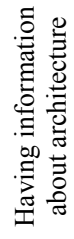 \\
\hline $\begin{array}{l}\text { Measure/Ratio/Propo } \\
\text { rtion }\end{array}$ & 7 & 14 & 76 & 151 & 104 & 0 & 0 \\
\hline Harmony & 5 & 32 & 98 & 140 & 77 & 0 & 0 \\
\hline Contrast & 12 & 46 & 101 & 121 & 72 & 0 & 0 \\
\hline Dominance & 16 & 38 & 92 & 113 & 93 & 0 & 0 \\
\hline Texture & 12 & 38 & 93 & 128 & 81 & 0 & 0 \\
\hline Hierarchy & 18 & 47 & 99 & 112 & 76 & 0 & $\Delta$ \\
\hline Repetition-Rhythm & 7 & 14 & 56 & 105 & 170 & 0 & 0 \\
\hline $\begin{array}{l}\text { Symmetry- } \\
\text { Asymmetry }\end{array}$ & 5 & 7 & 43 & 97 & 200 & 0 & 0 \\
\hline Unity & 13 & 36 & 107 & 131 & 65 & $\Delta$ & 0 \\
\hline $\begin{array}{l}\text { Figure-Ground } \\
\text { relationship }\end{array}$ & 10 & 40 & 112 & 132 & 58 & 0 & 0 \\
\hline $\begin{array}{l}\text { Light-Shadow } \\
\text { relationship }\end{array}$ & 13 & 39 & 102 & 103 & 95 & $\Delta$ & 0 \\
\hline $\begin{array}{l}\text { Solid-Void } \\
\text { relationship }\end{array}$ & 6 & 26 & 78 & 133 & 109 & 0 & 0 \\
\hline
\end{tabular}


214 Kirci - The difficulties of DESIGN TRAIN-ing

Table 8

Ranks Grouping Variable: drawing talent

Test Statistics (a)

\begin{tabular}{|c|c|c|c|c|}
\hline $\begin{array}{l}\text { Basic Design } \\
\text { Principles }\end{array}$ & $\begin{array}{c}\text { Mann-Whitney } \\
\text { U }\end{array}$ & Wilcoxon W & Z & $\begin{array}{l}\text { Asymp. Sig. } \\
\text { (2-tailed) }\end{array}$ \\
\hline $\begin{array}{l}\text { Measure/Ratio/ } \\
\text { Proportion }\end{array}$ & 11874.00 & 16627.00 & -0.615 & 0.539 \\
\hline Harmony & 12203.00 & 44843.00 & -0.203 & 0.839 \\
\hline Contrast & 12187.50 & 44827.50 & -0.219 & 0.826 \\
\hline Dominance & 11947.50 & 16700.50 & -0.511 & 0.610 \\
\hline Texture & 11337.50 & 43977.50 & -1.259 & 0.208 \\
\hline Hierarchy & 12239.50 & 16992.50 & -0.155 & 0.877 \\
\hline $\begin{array}{l}\text { Repetition- } \\
\text { Rhythm }\end{array}$ & 12157.00 & 16910.00 & -0.267 & 0.790 \\
\hline $\begin{array}{l}\text { Symmetry- } \\
\text { Asymmetry }\end{array}$ & 11809.000 & 44449.000 & -0.735 & 0.462 \\
\hline Unity & 10552.000 & 43192.000 & -2.228 & 0.026 \\
\hline $\begin{array}{l}\text { Figure-Ground } \\
\text { relationship }\end{array}$ & 11197.500 & 43837.500 & -1.439 & 0.150 \\
\hline $\begin{array}{l}\text { Light-Shadow } \\
\text { relationship }\end{array}$ & 9808.500 & 42448.500 & -3.112 & 0.002 \\
\hline $\begin{array}{l}\text { Solid and void } \\
\text { relationship }\end{array}$ & 11445.500 & 44085.500 & -1.136 & 0.256 \\
\hline
\end{tabular}


REMIE - Multidisciplinary Journal of Educational Research, 7(2) 215

Table 9.

Ranks grouping variable: previous information

Test Statistics (a) Mann-Whitney Test

\begin{tabular}{|c|c|c|c|c|}
\hline $\begin{array}{l}\text { Basic Design } \\
\text { Principles }\end{array}$ & $\begin{array}{c}\text { Mann-Whitney } \\
\text { U }\end{array}$ & Wilcoxon W & $\mathrm{Z}$ & $\begin{array}{l}\text { Asymp. Sig. } \\
\text { (2-tailed) }\end{array}$ \\
\hline $\begin{array}{l}\text { Measure/Ratio/ } \\
\text { Proportion }\end{array}$ & 10453.50 & 14731.50 & -1.909 & .056 \\
\hline Harmony & 11726.50 & 16004.50 & -.293 & .770 \\
\hline Contrast & 10655.50 & 14933.50 & -1.617 & .106 \\
\hline Dominance & 11283.00 & 15561.000 & -.837 & .402 \\
\hline Texture & 10979.50 & 15257.50 & -1.219 & .223 \\
\hline Hierarchy & 10017.50 & 14295.50 & -2.397 & .017 \\
\hline $\begin{array}{l}\text { Repetition- } \\
\text { Rhythm }\end{array}$ & 11926.00 & 16204.00 & -.044 & .965 \\
\hline $\begin{array}{l}\text { Symmetry- } \\
\text { Asymmetry }\end{array}$ & 10780.000 & 15058.000 & -1.579 & 0.114 \\
\hline Unity & 11230.00 & 15508.00 & -0.911 & 0.362 \\
\hline $\begin{array}{l}\text { Figure-Ground } \\
\text { relationship }\end{array}$ & 10952.000 & 15230.000 & -1.260 & 0.208 \\
\hline $\begin{array}{l}\text { Light-Shadow } \\
\text { relationship }\end{array}$ & 11824.000 & 16102.000 & -0.168 & 0.866 \\
\hline $\begin{array}{l}\text { Solid and void } \\
\text { relationship }\end{array}$ & 10787.500 & 15065.500 & -1.469 & 0.142 \\
\hline
\end{tabular}

